\title{
Literature Visualization Analysis of Domestic Technology Transfer Research Based on UCINET
}

\author{
Zetao Zhang \\ International Business School \\ Yunnan University of Finance and Economics \\ Kunming, China \\ 654122173@qq.com
}

\author{
Ersi Liu* \\ International Business School \\ Yunnan University of Finance and Economics \\ Kunming, China \\ Liuersi907@126.com
}

\begin{abstract}
Based on the bibliometrics software UCINET, a visual analysis was conducted on 898 papers with CSSCI in CNKI journal database from 2000 to 2019 by using the method of social network analysis. It is found that domestic technology transfer mainly focuses on the concept and function, mode and mechanism, influencing factors and performance evaluation of technology transfer, and the scope of technology transfer is mainly between developed countries and developing countries and domestic regions. Therefore, the mechanism of technology transfer between developing countries, the geographical barriers to technology transfer at the macro level, and the coordination of the interests of various subjects in technology transfer at the application level will become the hot topics of technology transfer research in the future.
\end{abstract}

Keywords: UCINET, technology transfer, visual analysis, research hotspot

\section{INTRODUCTION}

Technology transfer refers to the flow of a certain technology or knowledge in space, that is, the process of transferring from a country or region to another country or region in a certain form. Because of its typical geographic space flow and diffusion characteristics, technology or knowledge can be transferred like commodities with the expansion of trade. Neoclassical growth theory holds that technology transfer is an important source of technological progress in the later developing regions. Romer(1986), a theorist of new economic growth, further improved it and proposed that technological progress was the driving force of industrial innovation and economic growth, and that technology transfer was an important way to promote technological progress [1]. Adam Smith (1776) believed that in a closed society, foreign trade can promote the development of domestic resources and technological progress, and ultimately achieve the growth of wealth [2]. It can be said that technology transfer drives technology progress, which promotes industrial innovation and economic growth, and foreign trade has been running through it and played a "catalytic" role. Because technology transfer plays a crucial role in the development of national economy, the research on technology transfer has never stopped. In the face of the complicated research clue, in order to grasp the hot spots and directions of technology transfer from the macro level, the metrology software UCINET was used for reference to present the research results in the field of technology transfer in the past 20 years in the form of knowledge map.

\section{DATA SOURCES AND PROCESSING}

\section{A. Data source}

Representative, in order to ensure the feasibility of research and select the "China National Knowledge Infrastructure" journal database (CNKI) as literature retrieval platform, in advanced search and the search term "technology transfer", retrieve the item "key words", retrieval time for the 20 years, "2000-2019" literature source category for "CSSCI" for precise retrieval, after excluding the title clearly irrelevant literature, a total of 898 articles and related literature as the research sample.

B Data cleaning

\section{1) delete and merge keywords}

Limited to the fact that the author expresses the same meaning in different ways, through data cleaning, many keywords can initially reach the requirements of unification

\footnotetext{
*Corresponding author
} 
and standardization. There are two principles for keyword selection. One is to delete irrelevant words such as "suggestion", "summary" and "revelation". The second is to merge synonyms, the same meaning with different words expressed by the keyword into one. Specific results are shown in table 1.

\begin{tabular}{|c|c|c|}
\hline \multicolumn{3}{|c|}{ Cleaning type } \\
\hline $\begin{array}{l}\text { Deletion of } \\
\text { irrelevant }\end{array}$ & \multicolumn{2}{|c|}{$\begin{array}{l}\text { Summary, empirical research, Suggestions and } \\
\text { enlightenment Such obviously irrelevant words } 21\end{array}$} \\
\hline \multirow{8}{*}{$\begin{array}{l}\text { Synonym } \\
\text { merging }\end{array}$} & $\begin{array}{l}\text { Merged } \\
\text { keywords }\end{array}$ & Pre-merge keywords \\
\hline & college & $\begin{array}{l}\text { Universities, local universities, } \\
\text { institutions of higher learning, etc }\end{array}$ \\
\hline & $\begin{array}{l}\text { Technology } \\
\text { transfer }\end{array}$ & $\begin{array}{l}\text { Military technology transfer, } \\
\text { technology transfer system, etc }\end{array}$ \\
\hline & $\begin{array}{l}\text { Technology } \\
\text { transfer } \\
\text { model }\end{array}$ & $\begin{array}{l}\text { Service mode, knowledge double } \\
\text { helix model, triple helix, etc }\end{array}$ \\
\hline & $\begin{array}{l}\text { Technology } \\
\text { market }\end{array}$ & $\begin{array}{l}\text { Science and technology big market, } \\
\text { marketization, market economy, }\end{array}$ \\
\hline & $\begin{array}{l}\text { Technology } \\
\text { transfer } \\
\text { efficiency }\end{array}$ & $\begin{array}{l}\text { Two-stage DEA, DEA model, } \\
\text { efficiency, measurement, efficiency } \\
\text { evaluation, etc }\end{array}$ \\
\hline & $\mathrm{R} \& \mathrm{~d}$ & $\begin{array}{l}\text { R\&d investment, internal } \mathrm{R} \& \mathrm{~d} \text {, } \\
\text { independent } \mathrm{R} \& \mathrm{~d}, \quad \mathrm{R} \& \mathrm{~d} \\
\text { internationalization, etc }\end{array}$ \\
\hline & FDI & $\begin{array}{l}\text { Introduce FDI, bilateral FDI, foreign } \\
\text { investment policy, etc }\end{array}$ \\
\hline
\end{tabular}

\section{2) descriptive statistical analysis}

According to the above principles, the number of keywords, the degree of relevance and the effect of drawing are taken into comprehensive consideration. The words with the frequency of keywords appearing more than 6 times are called high frequency words (including 6 times). A total of 50 high frequency keywords are selected and made into a table, as shown in table 2 .
Table 2 research on technology transfer in China derived from statistics of high-frequency keywords in CSSCI articles (part)

\begin{tabular}{|c|c|c|c|c|c|}
\hline $\begin{array}{l}\text { numbe } \\
\mathrm{r}\end{array}$ & keywords & $\begin{array}{l}\text { Word } \\
\text { frequenc } \\
\text { y (sub) }\end{array}$ & $\begin{array}{l}\text { numbe } \\
\mathrm{r}\end{array}$ & keywords & $\begin{array}{l}\text { Word } \\
\text { frequenc } \\
\text { y (sub) }\end{array}$ \\
\hline 1 & $\begin{array}{l}\text { Technology } \\
\text { transfer }\end{array}$ & 651 & 26 & $\begin{array}{l}\text { Technology } \\
\text { import }\end{array}$ & 15 \\
\hline 2 & $\begin{array}{l}\text { Technology } \\
\text { transfer }\end{array}$ & 132 & 27 & $\begin{array}{l}\text { The United } \\
\text { States }\end{array}$ & 14 \\
\hline 3 & college & 114 & 28 & $\begin{array}{l}\text { Economic } \\
\text { growth }\end{array}$ & 11 \\
\hline 4 & $\begin{array}{l}\text { Transformatio } \\
\mathrm{n} \text { of } \\
\text { technological } \\
\text { achievements }\end{array}$ & 65 & 29 & $\begin{array}{l}\text { Cultural } \\
\text { friction }\end{array}$ & 11 \\
\hline 5 & $\begin{array}{l}\text { Multinational } \\
\text { companies }\end{array}$ & 64 & 39 & $\begin{array}{l}\text { The } \\
\text { enterprise } \\
\text { managemen } \\
\text { t }\end{array}$ & 11 \\
\hline 6 & $\begin{array}{l}\text { Innovation } \\
\text { environment }\end{array}$ & 56 & 31 & $\begin{array}{l}\text { Advances } \\
\text { in } \\
\text { technology }\end{array}$ & 9 \\
\hline 7 & $\begin{array}{l}\text { Intellectual } \\
\text { property } \\
\text { protection }\end{array}$ & 52 & 32 & $\begin{array}{l}\text { Financial } \\
\text { managemen } \\
\mathrm{t}\end{array}$ & 9 \\
\hline 8 & $\begin{array}{l}\text { Technology } \\
\text { innovation }\end{array}$ & 50 & 33 & $\begin{array}{l}\text { University } \\
\text { technology } \\
\text { transfer }\end{array}$ & 8 \\
\hline 9 & $\begin{array}{l}\text { Technology } \\
\text { transfer model }\end{array}$ & 44 & 34 & Japan & 8 \\
\hline 10 & $\begin{array}{l}\text { Quantity and } \\
\text { quality of } \\
\text { patents }\end{array}$ & 42 & 35 & $\begin{array}{l}\text { Innovation } \\
\text { post }\end{array}$ & 8 \\
\hline
\end{tabular}

\section{3) co-occurrence matrix}

According to the 50 high-frequency keywords extracted from 898 core journals, COOC software is used to convert them into co-occurrence matrix, as shown in table 3 below 
Table 3 co-occurrence matrix of high-frequency keywords in CSSCI

journal articles in domestic technology transfer studies (part)

\begin{tabular}{|c|c|c|c|c|c|c|c|}
\hline & $\begin{array}{l}\text { Tech } \\
\text { nolog } \\
\text { y } \\
\text { transf } \\
\text { er }\end{array}$ & $\begin{array}{l}\text { Tech } \\
\text { nolog } \\
\text { y } \\
\text { transf } \\
\text { er }\end{array}$ & $\begin{array}{l}\text { col } \\
\text { leg } \\
\mathrm{e}\end{array}$ & $\begin{array}{l}\text { Transf } \\
\text { ormati } \\
\text { on of } \\
\text { technol } \\
\text { ogical } \\
\text { achieve } \\
\text { ments }\end{array}$ & $\begin{array}{l}\text { Multi } \\
\text { nation } \\
\text { al } \\
\text { compa } \\
\text { nies }\end{array}$ & $\begin{array}{l}\text { Innov } \\
\text { ation } \\
\text { envir } \\
\text { onme } \\
\text { nt }\end{array}$ & $\begin{array}{l}\text { Intell } \\
\text { ectua } \\
1 \\
\text { prop } \\
\text { erty } \\
\text { prote } \\
\text { ction }\end{array}$ \\
\hline $\begin{array}{l}\text { Techno } \\
\text { logy } \\
\text { transfer }\end{array}$ & 0 & 33 & 93 & 35 & 47 & 39 & 37 \\
\hline $\begin{array}{l}\text { Techno } \\
\text { logy } \\
\text { transfer }\end{array}$ & 33 & 0 & 5 & 2 & 10 & 4 & 16 \\
\hline college & 93 & 5 & 0 & 15 & 4 & 6 & 4 \\
\hline $\begin{array}{l}\text { Transf } \\
\text { ormati } \\
\text { on of } \\
\text { technol } \\
\text { ogical } \\
\text { achieve } \\
\text { ments }\end{array}$ & 35 & 2 & 15 & 0 & 3 & 2 & 1 \\
\hline $\begin{array}{l}\text { Multin } \\
\text { ational } \\
\text { compa } \\
\text { nies }\end{array}$ & 47 & 10 & 4 & 3 & 0 & 3 & 3 \\
\hline $\begin{array}{l}\text { Innovat } \\
\text { ion } \\
\text { environ } \\
\text { ment }\end{array}$ & 39 & 4 & 6 & 2 & 3 & 0 & 4 \\
\hline $\begin{array}{l}\text { Intellec } \\
\text { tual } \\
\text { propert } \\
\mathrm{y} \\
\text { protecti } \\
\text { on }\end{array}$ & 37 & 16 & 4 & 1 & 3 & 4 & 0 \\
\hline
\end{tabular}

\section{THE DATA ANALYSIS}

The high-frequency keyword co-occurrence matrix shown in figure 3 was imported into the software of UCINET for social network analysis, and the social network diagram of
50 keywords was obtained as shown in figure 1.

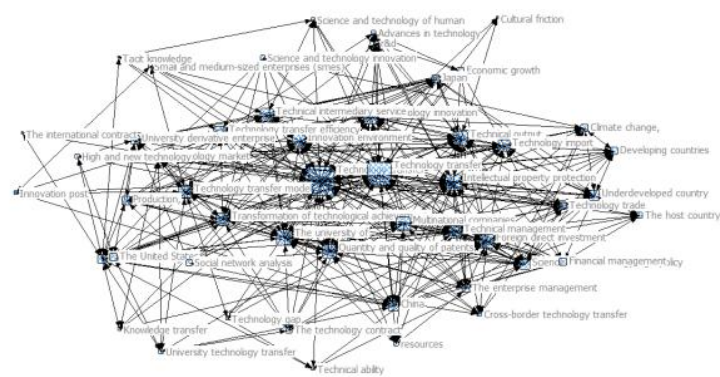

Figure 1 common word network diagram of high frequency keywords

As can be seen from figure 2 , there are 50 nodes of technology transfer in the figure, which exactly correspond to 50 high-frequency keywords. All points are connected with each other by arrows, indicating that there is a certain correlation between them. At the same time as you can see, technology transfer, technology transfer mode, the factors influencing efficiency of technology transfer, technology transfer, in a center position, the key words are gathered figure shows that domestic technology transfer is the core of hotspot research problems, the following through the density and specific analysis of domestic technology transfer centricity.

A overall network density analysis

Table 4 overall network density table of high frequency keywords

\begin{tabular}{|l|l|l|}
\hline \multirow{2}{*}{$\begin{array}{l}\text { The density of the } \\
\text { decision }\end{array}$} & Density & No. of Ties \\
\cline { 2 - 3 } & 0.2939 & 720.0000 \\
\hline
\end{tabular}

Network density mainly measures the degree of tightness among the main members of the network. For this study, the higher the overall network density is, the more concentrated the research problems are. It is measured by the ratio of the number of relationships the network actually contains to the maximum number of relationships the network may have. According to calculation, the overall network density in FIG.2 is 0.2939. It can be considered that the research problems of this network are relatively concentrated and the relations between members are relatively close.

\section{B Centrality analysis}

\section{1) Degree Centralization}


Table 5 centrality table of high frequency keywords (part)

\begin{tabular}{|l|l|l|l|l|}
\hline number & keywords & Degree & NrmDegree & Share \\
\hline 1 & Technology transfer & 816.000 & 17.907 & 0.256 \\
\hline 2 & Technology transfer & 230.000 & 5.047 & 0.072 \\
\hline 3 & college & 201.000 & 4.411 & 0.063 \\
\hline 5 & Multinational companies & 120.000 & 2.633 & 0.038 \\
\hline 7 & Intellectual property protection & 113.000 & 2.480 & 0.035 \\
\hline 16 & Technical management & 98.000 & 2.151 & 0.031 \\
\hline 6 & Innovation environment & 93.000 & 2.041 & 0.029 \\
\hline 11 & fdi & 93.000 & 2.041 & 0.029 \\
\hline 10 & Quantity and quality of patents & 92.000 & 2.019 & 0.029 \\
\hline
\end{tabular}

Degree Centralization is an index used to measure the position of nodes in the network. Point centrality is the idea that if a point is connected to a number of nodes, that node is at the center of the network and has more "power", usually measured by the number of points directly connected to that node. According to the calculation results of UNCIT, the average point centrality of all high frequency words is 63.68 . This means that "technology transfer", "intellectual property protection", "foreign direct investment", "technology transfer mode", "technology intermediary services", "technology transfer efficiency" and 14 other keywords are above the average degree of centrality. Visible. These keywords are in the middle of the overall network, consistent with figure 1 , and they are the focus of research in the area of technology transfer.

\section{2) closeness centralization}

Table 6 high frequency keywords near centrality table (part)

\begin{tabular}{|l|l|l|l|}
\hline number & keywords & Farness & nCloseness \\
\hline 1 & Technology transfer & 50.000 & 98.000 \\
\hline 2 & Technology transfer & 59.000 & 83.051 \\
\hline 3 & college & 72.000 & 68.056 \\
\hline 7 & Intellectual property protection & 72.000 & 68.056 \\
\hline 11 & fdi & 74.000 & 66.216 \\
\hline 10 & Quantity and quality of patents & 74.000 & 66.216 \\
\hline 8 & Technology innovation & 75.000 & 65.333 \\
\hline 13 & Technical output & 75.000 & 65.333 \\
\hline 5 & Multinational companies & 75.000 & 65.333 \\
\hline
\end{tabular}

closeness centralization measures the centrality of a point. In a graph, the smaller the total distance from one point to all other points, the stronger the ability of the point to be "out of the control" of others. The higher the centrality is, the better the view is in the network, which can know what is happening in the network and the direction of information flow. According to the calculation results of UCINET, the minimum centrality of technology transfer is 50, indicating that technology transfer has a good "vision" in the overall network and can reach the nodes of other keywords with the shortest distance. In addition, "universities", "foreign direct investment", "quantity and quality of patents", "Technological innovation" and other keywords are also lower than the average level of centrality, indicating that these keywords are closely related to other keywords and should be added to the current research hotspots.

\section{3) Betweenness centralization}

Table 7 middle centrality table of high frequency keywords (part)

\begin{tabular}{|c|l|c|c|}
\hline number & keywords & FlowBet & nFlowBet \\
\hline 1 & Technology transfer & 970.053 & 41.244 \\
\hline 2 & Technology transfer & 218.002 & 9.269 \\
\hline 3 & college & 72.960 & 3.102 \\
\hline 4 & Transformation of & 41.906 & 1.782 \\
\hline 5 & technological achievements & & \\
\hline 6 & Innovation environment & 37.545 & 1.596 \\
\hline 7 & Intellectual property & 60.460 & 2.571 \\
\hline 8 & protection & & \\
\hline 9 & Technology innovation & 49.254 & 2.094 \\
\hline
\end{tabular}

In a network, if a point is on a path between many other two points, it can be considered important because it has the "ability" to control the interaction between the other two points. According to the calculation results of UCINET, the median centrality of all high-frequency keywords is 48.475 , so it can be seen that the median centrality of "technology transfer", "technology transfer mode", "technology output", "influencing factors" and other keywords is higher than the average. It can be seen that these keywords are also from the path between many other two points, and they are closely related to other keywords, so they should be included in the research hotspots. 


\section{CONCLUSIONS AND SUGGESTIONS}

In summary, it can be seen from the above analysis that in the past 20 years, a large number of studies have been conducted on technology transfer. According to UCINET calculation results and its analysis we can know, in the words of "technology transfer", "technology transfer model", "the protection of intellectual property rights", "impact factor" and "university" as the core of common words in the network to form the four most of the content: the first is about the concept of technology transfer and its effect; The second is the mode and mechanism of technology transfer. The third is the research on the influencing factors of technology transfer. The fourth is the performance evaluation of technology transfer. In addition, the existing technology transfer mainly focuses on two aspects: one is the technology transfer from developed countries to developing countries, and the other is the domestic regional technology transfer.

Therefore, the current domestic technology transfer research has some limitations, mainly lies in the following aspects: one is in terms of mechanism, most studies are concentrated in developed countries to developing countries transfer, the role of multinational corporations as the main body of technology transfer is more, but few research achievements of technology transfer between developing countries, lack of technology and study the mechanism of the cross between industry and trade; Second, at the macro and micro level, from the perspective of cross-border technical cooperation mechanism, how to solve the geographical barrier effect and the unbalanced development between neighboring countries and regions through technology transfer, especially the problem of cross-border coordinated economic and social development, is the fundamental problem to deepen the good-neighborly friendship and long-term peace and stability of countries. The third is how to form an effective cooperation mechanism among governments, enterprises and projects. These three aspects are not only the shortcomings of domestic technology transfer, but also the critical problems that must be solved in the process of technology transfer. Therefore, these three aspects will become the research focus and direction of technology transfer in the future.

\section{ACKNOWLEDGMENT}

This study obtained the Yunnan university of finance and economics graduate student innovation fund project "The Lancang-Mekong river cooperation mechanism under the study of the influence factors of technology transfer of cross-border (2019YUFEYC011) support, first of all thanks for Yunnan university of finance and give me the material and spiritual support, secondly thank teacher tireless edification and spiritual encouragement to me, thank you finally Yunnan university of finance and economics and international business school, offers this platform, and reviewing the teacher review and recommendations, expressed sincere gratitude.

\section{REFERENCES}

[1]Paul m. Romer. Increasing Revenue and long-term Growth[J]. Journal of Political Economy,1986(21):4-26

[2] Adam Smith. An inquiry into the nature and causes of the wealth of nations[M]. 2013.

[3] liu jun. Overall network analysis handout :UCINET software practical guide [M]. Beijing: ge zhi press, 2014:10-33

[4]Si shangqi, feng feng. Research on cross-regional technology transfer alliance based on symbiotic network in China [J]. Science of science and technology management,2009,30(10):48-52.

[5] fan jianting, wang li, export orientation, technology types and internal technology transfer of transnational corporations -- an empirical analysis based on japanese-invested enterprises in China [J]. Financial and economic research, 2015, 41(10) : 83-95. 